\author{
MAGDALENA OCHWAT \\ (D) https://orcid.org/ 0000-0002-0178-165X \\ Uniwersytet Śląski \\ Katowice
}

\title{
Klimat - konflikty - migracje. Scenariusze przyszłości
}

Climate - conflicts - migrations. Scenarios for the future

\begin{abstract}
The paper addresses the issue of refugees in the broad sense of the term, i.e. people forced to leave their homes and seek conditions for a normal life due to climate change and to the excessive environment footprint left by humans. The numerous reasons for this type of displacement include drought, the growing scarcity of natural resources in seas and oceans, and the unfair distribution of water. These three climate plagues are analysed on the basis of non-fiction literature - Wykluczeni [The Excluded], which is a book of reportage by Artur Domosławski, Ben Rawlence's City of Thorns. Nine Lives in the World's Largest Refugee Camp, and Stefano Liberti's South of Lampedusa. In the public consciousness, migrations motivated by climate change and human interference in the ecosystem have been functioning since recently, but they will actually become the greatest challenge of our day and age. This is why the important role played by humanities is to speak about them, to comment on their performative power, to debate on potential solutions, and to trigger warning discourses leading to the development of a habit of imagining "scenarios for the future". Acts of imagination provide the possibility to shape the world in an unlimited way and to play out in a virtual manner some key social, cultural and political situations, in order to live well on an overcrowded planet, where water, land and food may be lacking a few decades from now.
\end{abstract}

Key words: migration, climate refugees, reportage, climate change, engaged humanities, Polish language and culture education

\section{Humanistyka zmiany}

Ryszard Nycz w ksiazżce Kultura jako crasownik. Sondowanie nowej bumanistyki pisze, iż procesy migracyjne $\mathrm{i}$ wynikające $\mathrm{z}$ nich konsekwencje to jeden z najważniejszych tematów podejmowanych dziś przez nową humanistykę. 
Dzieje się tak ze względu na ich jednostkową i społeczną doniosłość, a także z uwagi na poziom emocji, konfliktów - racji oraz sporów, które im towarzyszą (Nycz 2017, 117). To one wywołują lęk o naszą przyszłość. Wszak masowa mobilność ma ogromny wpływ na przemiany polityczne, ekonomiczne, społeczne i kulturowo-tożsamościowe, a władze niektórych państw już uczyniły z niej kartę przetargową w debacie publicznej.

Można przypuszczać, że ruchy migracyjne nie są stanem chwilowym, dotyczącym tylko początku XXI wieku, wiele przemawia za ich permanentnym charakterem. Zakłada się bowiem, że stopniowe, ale finalnie radykalne zmiany klimatyczne pociagna za sobą niespotykaną do tej pory rzeszę ludzi szukających „normalnego” życia. Artur Domosławski w książce pt. Wykluczeni, w podrozdziale pod znaczącym dla niniejszych rozważań tytułem Wojny klimatyczne i nowa Zagłada - przewiduje, że

Falę migracyjna z 2015 roku będziemy wspominać z nostalgia, a dzisiejsze uniesienia polemiczne wydadzą się śmieszne, groteskowe. W przyszłości za szansę przyzwoitej egzystencji w świecie zniszczonym nie tylko wojnami, lecz także zmianami klimatycznymi, pod wielokrotnie większym naporem migrantów z terytoriów, na których nie da się żyć, oddamy bez mrugnięcia [okiem - M.O.] nasze swobody i uświęcone wartości (Domosławski 2016, 377).

Trzeba przyznać, że dziennikarz trafnie uchwycił apokaliptyczną wizję Ziemi zniszczonej wojnami i zmianami klimatycznymi, której przyszłość zdominuje exodus milionów ludzi. Zmieni on kompletnie oblicze naszych społeczeństw. Prowadzone spory o tożsamość i wartości, w tym wartości chrześcijańskie, odejdą na dalszy plan, liczyć się będzie tylko przetrwanie.

W świadomości społecznej migracje motywowane zmianami klimatu i ingerencją człowieka w ekosystem funkcjonują od niedawna - pojawiły się po spustoszeniu przez huragan Katrina południowo-wschodniego wybrzeża USA w 2005 roku - i to one staną się największym wyzwaniem nowoczesności (Welzer 2010, 43-44). Wprawdzie masowe przemieszczenia z Azji i Afryki do Europy już się rozpoczęły, a sam temat, rzecz jasna, nie jest nowy - ważne głosy klimatologów oraz przyrodników od dawna pojawiały się w debacie publicznej - to jednak mamy stosunkowo niewiele czasu, by się do niego przygotować.

W tym kontekście upatruję szczególnej roli humanistyki, która powinna aktywnie włączać nowe dyskursy krytyczne na temat „kultury odrzucenia” 
Innych, „globalizacji obojętności” czy „kultury dobrobytu”, ale przede wszystkim uruchamiać dyskursy ostrzegające przed katastrofalnymi zmianami klimatycznymi. Ten zakres tematyczny wpisuje się w obszar humanistyki zaangażowanej (w sprawy społeczne, polityczne, środowiskowe, ekonomiczne, kulturowe) w problemy współczesnego świata. Powinien on obejmować również działania prowadzące do wyrobienia nawyku wyobrażania sobie alternatywnych wizji przyszłości oczekiwanej albo nawet tej jeszcze niepomyślanej - po to, by wcześniej alarmować o ewentualnych zagrożeniach, dokonywać zmian i współtworzyć lepszy świat. Niektórzy tę ważna, wieszczącą rolę humanistów nazywają niewdzięcznie: „sianiem paniki”. Mianem osoby „siejącej panikę” okrzyknięto m.in. Günthera Andersa, wielkiego filozofa ery Auschwitz, Kołymy i Nagasaki, który określenie to traktował jako zaszczyt i honor. Według niego „najważniejszym zadaniem moralnym jest uświadamianie ludzi, iż winni się czuć zaalarmowani i że lęki, jakie ich gnębią, nie są bezzasadne” (Welzer 2010, 13).

Inni, jak Ewa Domańska, piszą o „humanistyce prefiguratywnej, która jest w stanie wyobrazić sobie przyszłość »zawczasu«; niejako zwiastuje jej nadejście, a jednocześnie bierze udział w kształtowaniu możliwych scenariuszy przyszłości (łac. prae, pre- + łacińskie figürāre, kształtować; od figūra kształt)" (Domańska 2017, 49). Celem humanistyki prefiguratywnej byłoby prewencyjne działanie ante factum, a nie post factum (Domańska 2017, 43) i dążenie dzięki temu do zmiany. Nie będę przywoływała ustaleń poznańskiej badaczki dotyczących „nie/sprawiedliwości epistemicznej”, „krytycznej nadziei” czy tworzenia „odpowiedzialnych utopii”, choć z pewnością jako metody badań nowej humanistyki warto byłoby je szczegółowo przybliżyć. Odnosząc się do prowadzonych w tym tekście rozważań, skupię się jedynie na kierunku postrzegania humanistyki jako nauki, która określa „możliwość zmian” (Domańska 2017, 52). Humaniści stają się więc „sygnalistami”, jak nazwał ich trafnie Ryszard Koziołek, którzy podnoszą alarm w sytuacji zagrożenia.

Sygnalista to ktoś, kto zwraca publicznie uwagę na zło (...) w społeczności, do której sygnalista należy. Termin „whistle-blower” pojawił się w anglosaskiej kulturze politycznej w latach 60 . XX w., choć nazwa istnieje tam co najmniej od wieku XIX, kiedy oznaczał używających gwizdka policjantów i sędziów sygnalizujących złamanie reguł gry. Ostrzegaw-

\footnotetext{
${ }^{1}$ Kategorie „kultury odrzucenia”, „kultury dobrobytu”, „globalizacji obojętności” podaję za
} Papieżem Franciszkiem. Por. Domosławski 2016, 135-136, za: Ojciec Święty Franciszek 2015. 
czy gwizd humanisty ma inny charakter niż sygnalisty zgłaszającego nieprawidłowości (...). Odgwizduje on faul, którego jeszcze nie popełniono. Humanistyka wytwarza w nas potrzebę i zdolność do wypowiadania indywidualnej niezgody lub tylko niepokoju wobec tego, co jest lub może być. Kształcenie humanistyczne przygotowuje „sygnalistę”, czyli człowieka zdolnego do nazywania tego, co nadchodzi².

Na humanistyce spoczywa zatem ogromna odpowiedzialność wykształcenia umiejętności przewidywania niepożądanych skutków różnych działań w przyszłości oraz ostrzeganie przed nimi. Trzeba przyznać, że w dobie kryzysu wyobraźni ${ }^{3}$, który wydaje się stać również za niezrozumieniem zmian klimatycznych ${ }^{4}$, są to zadania dość trudne.

Ten niepokojący brak wyobraźni uwidacznia się także w interesującej mnie kwestii - migracji środowiskowej, mimo że już mniej więcej od lat 80. wiemy, co odróżnia ten typ uchodzenia od innych oraz jakie moga być jego przyczyny. Essam El-Hinnawi, egipski ekspert, jako jeden z pierwszych badaczy zdefiniował uchodźców środowiskowych (ang. environmental refugees) ${ }^{5}$ jako ludzi

którzy zostali zmuszeni do tymczasowego lub stałego opuszczenia swoich tradycyjnych domostw z powodu znaczącego naruszenia środowiska

2 Wykład Ryszarda Koziołka pt. Humanista sygnalista wygłoszony został w trakcie konferencji Spoteczeństwo obywatelskie: edukacja, wartości, style komunikacyjne organizowanej w dniach 89.06.2018 roku na Uniwersytecie Śląskim w Katowicach, http://www.spoleczen stwoobywatelskie.edu.pl/\#p=13. Cytowana wypowiedź pochodzi z: http://www.interakcja-integracja2018.us.edu.pl/humanista-sygnalista/ [dostęp: 23.02.2019].

3 Określenie „kryzys wyobraźni” w kontekście zmian klimatycznych zostało użyte przez Amitava Ghosha. Zob. również: Ghosh 2016. „The climate crisis is also a crisis of culture, and thus of the imagination”. Wszystkie tłumaczenia, jeśli nazwisko tłumacza nie zostało podane, pochodzą od autorki artykułu. Zob. także Fiedorczuk 2015.

${ }^{4}$ Por. np. wypowiedź Prezydenta RP, Andrzeja Dudy, w czasie szczytu klimatycznego w Katowicach w 2018 roku na temat zapasów węgla „na dwieście lat”.

5 Termin ,migrant środowiskowy” używany jest w literaturze przedmiotu zamiennie $\mathrm{z}$ innymi terminami: „uchodźca ekologiczny”, „uchodźca klimatyczny”, „uchodźca zmuszony do migracji z powodów dewastacji środowiska”, ,eko-uchodźca”, „osoba przesiedlona z powodów ekologicznych"(ang. ecological refugee, climate refugee, forced environmental migrant, eco-refugee, ecologically displaced person). Maciej Ząbek w książce Uchodźcy w Afryce. Etnografia przemocy i cierpienia pojęcie „uchodźstwo klimatyczne” odnosi tylko do uchodźstwa z powodów zmian klimatycznych w przeciwieństwie do "uchodźstwa środowiskowego” obejmującego inne, także środowiskowe przyczyny przymusowych przemieszczeń $(2018,133)$. Zgodnie z tym rozróżnieniem druga kategoria jest szersza. 
(spowodowanego przyczynami naturalnymi i/lub przez ludzi), które zagroziło ich istnieniu i/lub poważnie wpłynęło na jakość ich życia. Przez „naruszenie środowiska” w tej definicji rozumie się wszelkie fizyczne, chemiczne i/lub biologiczne zmiany w ekosystemie (lub zasobach), które czynia go, tymczasowo lub na stałe, nieodpowiednim do życia (Bates 2002, 466, za: El-Hinnawi 1985, 4) ${ }^{6}$.

Szkoła i uniwersytet nie podejmują tego istotnego tematu, uczniowie nie czytają lektur ${ }^{7}$ przygotowujących do myślenia ${ }^{8}$ i mówienia o uchodźstwie spowodowanym zmianami klimatycznymi, nie krytykują dostatecznie głośno postaw społecznych opartych na dyskryminacji czy mowie nienawiści kierowanej w ich stronę. Studenci nie konstruują alternatywnych scenariuszy naszej egzystencji w świecie zniszczonym wojnami i niepohamowaną eksploatacją zasobów naszej planety. Nie profilują kształtu imaginarium uchodzenia z powodów dewastacji ekosystemu i zmiany klimatu. Jednocześnie mamy do czynienia z milczeniem w naukach społecznych i kulturoznawczych, na co wskazuje Harald Welzer w głośnej książce Wojny klimatyczne: za co będziemy zabijać w XXI wieku, która głęboko zainspirowała mnie do niniejszych rozważań. Pisze on tak:

nieomal wszystkie rozprawy naukowe dotyczące zjawiska zmiany klimatu to studia z dziedziny nauk przyrodniczych, modele obliczeniowe i prognozy. Tymczasem po stronie nauk społecznych i kulturowych panuje cisza, tak jakby zjawiska (...) konfliktu o zasoby, masowych migracji, za-

6 "People who have been forced to leave their traditional habitat, temporarily or permanently, because of a marked environmental disruption (natural and/or triggered by people) that jeopardized their existence and/or seriously affected the quality of their life [sic]. By 'environmental disruption' in this definition is meant any physical, chemical, and/or biological changes in the ecosystem (or resource base) that render it, temporarily or permanently, unsuitable to support human life".

${ }^{7}$ Podręcznik szkolny realizujący ten temat to Nowe stowa na start!. Podręcznik do jezylka polskiego dla klasy siódmej szkoly podstawowej (Kościerzyńska, Chmiel, Szulc, Gorzałczyńska-Mróz 2017, 277). Podejmuje on interesujące nas zagadnienie we fragmencie z tekstu Imperium Ryszarda Kapuścińskiego, który opowiada o znikającym z ziemi Morzu Aralskim, a co za tym idzie - braku pożywienia i pracy dla wiosek przybrzeżnych. Kolejny rozdział w omawianym podręczniku rozpoczyna wywiad z reżyserem Wojciechem Szumowskim na temat jego reportaży o Syrii Ocaleni oraz Cena marzeń Syryjcayków.

${ }^{8}$ Zob. książkę Lekcje myślenia (obywatelskiego). Edukacja polonistycz̨na wobec wspótczesnego świata Krzysztofa Koca (2018), w które autor pokazuje, jak lekcje języka polskiego moga rozwijać zdolność myślenia o współczesności, w tym o problemie uchodźstwa na podstawie współczesnych reportaży. 
grożenia bezpieczeństwa, (...) ekonomii wojny i przemocy i tak dalej nie podlegały pod ich kompetencje (Welzer 2010, 46).

Choć cytowana myśl niemieckiego badacza powstała w 2008 roku i od tego czasu wiele się zmieniło, to jednak dalej emituje się za dużo gazów cieplarnianych, wylewa ścieki do rzek, betonuje miasta, wycina drzewa, ba, nawet ogromne połacie puszczy i lasów równikowych, nie zważa się na problem migracji środowiskowej, na zatapianie małych państw wyspiarskich. Nie zaktualizowano definicji prawno-formalnej „uchodźstwa” zapisanej w konwencji genewskiej o ten wymuszony przecież typ przemieszczeń ludzkich ${ }^{9}$. Wprowadza się za to coraz to nowe łagodzące konstrukty językowe, jak: „środowiskowa niesprawiedliwość” (environmental injustice), „środowiskowa nierówność" (environmental inequity) czy „rasizm środowiskowy” (environmental racism) w odniesieniu do rasy, etnosu, narodu czy klasy (Zabek 2018, 138). Nie ulega jednak wątpliwości, że skutki katastrof naturalnych, mających swe źródła i konsekwencje w działalności człowieka, powinny znaleźć się w kręgu priorytetowych interdyscyplinarnych badań naukowych. To również pole dla humanistyki ${ }^{10}$.

Refleksje humanistyczne dotyczące aktualnej kondycji Ziemi, zmian klimatycznych oraz ucieczki ludzi z miejsc zdewastowanych i zagrożonych moga brzmieć trochę mitycznie, wręcz nieprawdopodobnie, jak filmy science fiction spekulujące o wyniszczeniu planety, wojnach o przestrzeń, wodę i zasoby naturalne, jeśli nie umieści się ich w aktualnym kontekście. Amitav Ghosh, hindusko-bengalski autor literatury głównie fantastycznej, w jednej ze swoich ostatnich ksiązek (tym razem jak najbardziej realistycznej) pt. The Great Derangement: Climate Change and the Unthinkable zauważył, że kiedy pojawia się temat zmian klimatycznych, prawie zawsze odnosi się go albo do literatury faktu, albo do gatunku science fiction.

Sama wzmianka o temacie jest często wystarczająca, aby sprowadzić powieść lub opowiadanie do gatunku science fiction. Tak jakby w literackiej

${ }^{9}$ Badacze są w tym punkcie podzieleni. Zastanawiają się na przykład nad tym, kto jest prześladowcą tego typu uchodźców? Klimat, geografia, historia, własny nieudolny rząd, a może ci, do których uciekają? (Por. Ząbek 2018, 139).

10 Takie badania prowadzi się co najmniej od końca lat 70. zwłaszcza w amerykańskiej, kanadyjskiej i australijskiej humanistyce, gdzie humanistyka środowiskowa (environmental humanites) określana również ekologiczną (ecological) czy zrównoważoną (sustainable), jest bardzo rozwinięta. W Polsce ten nowy paradygmat naukowy dopiero zaczyna się rozwijać (por. Domańska 2013, 13-32, Derra 2013). 
wyobraźni zmiany klimatu były w jakiś sposób podobne do istot pozaziemskich lub podróży międzyplanetarnych. (...) uderzający jest fakt, że kiedy powieściopisarze decydują się na pisanie o zmianach klimatu, prawie zawsze są poza fikcja (Ghosh 2016) ${ }^{11}$.

Rację ma Ghosh, pisząc, że ekstremalne zjawiska pogodowe i ich konsekwencje wydają się nieprawdopodobne, co doprowadza do bycia na obrzeżach fikcji lub przynależności do gatunku science fiction ${ }^{12}$. Patrząc jednak na to, co dzieje się w realnym świecie, możemy zaobserwować, iż stopień nieprawdopodobieństwa zmienia się - wysoce niemożliwe zdarzenia stają się zdumiewająco realne.

Nie wchodząc jednak głębiej w ten problem i jego reprezentacje tekstowe, $\mathrm{w}$ artykule podejmuję temat przyczyn uchodzenia spowodowanego zmianami w środowisku na przykładzie literatury non-fiction. Przywołuję reportaże literackie Artura Domosławskiego, Wykluczeni (2010), Bena Rawlence'a Miasto Cierni. Najwiekeszy obóz dla uchodźców (2017), Stefana Libertiego Na Poludnie od Lampedusy. Podróże rozpaçyy (2013) dotyczące tego, co dzieje się dziś w niektórych państwach Afryki i Azji, Ameryki Południowej czy na Bliskim Wschodzie. Próbuję naświetlać teraźniejszość o możliwości przyszłych transformacji, alternatywnych wizji przyszłości, które mają nie tylko charakter globalny, ale także planetarny. To teraźniejszość i związane z nią zagrożenia, do których należy zaliczyć wzrost poziomu niesprawiedliwości społecznej, problemy środowiska czy konsekwencje ruchów migracyjnych stanowią punkt odniesienia w procesie budowania wiedzy o przyszłości. Ćwiczenia w odtwarzaniu drogi ku temu, co może nastąpić, świetnie sprawdzą się w przestrzeni szkolnej, a ich celem byłyby prewencyjne działania młodych. Tworzenie scenariuszy przyszłości powinno być wykorzystywane częściej jako metoda dydaktyczna na lekcjach języka polskiego i nie tylko. Ze względu na sam gatunek reportażu i jego cechy stanowi on doskonały materiał dydaktyczny dla innych przedmiotów: geografii, historii, WOS-u, biologii. Wychodząc od teraźniejszości reportażowej i opierając się na niej, można wspólnie z uczniami spekulować, stwarzać w projektowaniu przyszłości

11 "The mere mention of the subject is often enough to relegate a novel or a short story to the genre of science fiction. It is as though in the literary imagination climate change were somehow akin to extraterrestrials or interplanetary travel. (...) Yet, it is a striking fact that when novelists do choose to write about climate change it is almost always outside fiction".

12 Powstają nowe gatunki literackie i filmowe dotyczące tych tematów, takie jak: eko-fikcja, climate fiction (cli-fi), eco science fiction. 
koncepcje pozytywne i negatywne, wytyczać długofalowe plany odbudowy człowieka i świata, dawać nadzieję, że przede wszystkim od świadomych obywateli zależy zmiana oblicza naszej planety.

Jedną z ciekawych strategii tworzenia wizji przyszłości i „odgwizdywania” sytuacji niebezpiecznych, którą zapożyczam z zupełnie innym kontekstem (dalekim od analiz dyskursu władzy polityki amerykańskiej początku XXI wieku) od Briana Massumiego, kanadyjskiego krytyka kultury oraz teoretyka mediów, jest strategia pod nazwa , pokaż próbkę przyszłości” (sample the future, przeł. Tabaszewska 2017). Najłatwiej zastosować ją za pomocą dobrze zorganizowanej wojny informacyjnej.

Zgodnie z nią, przyszłość jest widziana jako deszcz iskier, z których tylko jedna ma szansę - jeśli spadnie na odpowiedni grunt - zapłonąć. Jednak dla potrzeb wojny informacyjnej każda $z$ tych iskier jest interesująca, każda ma szansę stać się przyszłością, a więc możemy wybrać dowolną (czyli niekoniecznie najbardziej prawdopodobna) z nich jako przykład mającej nastąpić, zagrażającej przyszłości (Tabaszewska 2017, 52 za: Massumi 2015, 117).

Myślenie futurologiczne jest nie tylko grą dydaktyczną, chwytliwą metodą służącą li tylko wciaganiu uczniów w nurt lekcji, to także świadectwo odpowiedzialności za przyszłość, która wpisana jest w szeroko pojmowaną humanistykę. Akcentuję więc przede wszystkim charakter formacyjny odczytywanej przyszłości - kształtowania ,jednostkowej wyobraźni moralnej” (Domańska 2017, 52) ${ }^{13}$ - niezbędny w misji społecznej edukacji.

Celem artykułu jest zilustrowanie reportażami literackimi przyczyn migracji motywowanej kryzysem środowiska naturalnego oraz zaproponowanie, nazwijmy je umownie, „ćwiczeń z przyszłości”. W analizowanych tekstach podkreślam po pierwsze: związki między klimatem, konfliktami a migracją, po drugie: relacje między biedą i niesprawiedliwością a kruchością naszej planety, wszak - powtarzam raz jeszcze za Welzerem - przyrodnicze kataklizmy zawsze są katastrofami społecznymi. Ponadto moją uwagę zajmują te fragmenty, które pokazują, że świat jest układem relacji - degradacja natury związana jest z największym exodusem, głównie do Europy. Ważna jest krytyka nieodpowiedzialnej władzy człowieka nad natura, a także wychowywanie i kształcenie młodych do życia we wspólnocie w duchu - używając kate-

13 Termin „wyobraźnia moralna” Ewa Domańska przywołuje za czołowym przedstawicielem amerykańskiego progresywizmu, pedagogiem Johnem Deweyem. 
gorii Papieża Franciszka - ekologii integralnej (zob. Ojciec Święty Franciszek 2015, 10). Na kwestie te powinny szeroko otworzyć się dziś szkoła i uniwersytet, przewidując - jak zaleca Ryszard Koziołek - „scenariusze przyszłości”, spekulując, co czeka nas w XXI wieku. Sygnał alarmowy już rozbrzmiał...

\section{Wojny o „niebieskie złoto" ${ }^{14}$}

Artur Domosławski w reportażu pt. Wykluczeni, wydanym w 2016 roku jako relacja z blisko dwudziestoletniej podróży po krajach Południa, wśród wielu historii ukazujących mechanizm wykluczania, które odnotował, zaobserwował również, że woda staje się przedmiotem największych sporów. Trudno sobie wyobrazić bardziej życiodajny surowiec, za pomocą którego można marginalizować, dyskryminować, a w końcu wypędzać i konfliktować ludzi. To efekt dostrzegalnego już braku wody pitnej, zmniejszania się liczby opadów, podwyższania temperatury, pustynnienia terenu. Problem przybierze na sile w nieodległej przyszłości. W 2050 roku dwa miliardy ludzi cierpieć będą na niedobór wody, najczarniejsze prognozy mówią nawet o siedmiu miliardach (Welzer 2010, 113).

Reporter pokazuje (współ)egzystencję Palestyńczyków z Izraelczykami na jednym skrawku ziemi od momentu powstania państwa żydowskiego aż do czasów współczesnych. Ich początkowe relacje układały się poprawnie - żydowscy osadnicy zatrudniali Beduinów do budowania domów, pielęgnowania ogrodów czy sprzątania. Współcześnie jednak ich życie wygląda zupełnie inaczej. Dawni koczownicy są izolowani za pomocą murów i sieci dróg, po których nie moga chodzić, lub przez odcięcie im dostępu do wody pitnej. Prowadzi się z nimi „cichą wojnę” o zasoby naturalne za pomocą kontrolowania zbiorników wodnych. Ich życie - jak pisze autor - znajduje się w podwójnej pułapce, zarówno przestrzennej - na palestyńskich terytoriach okupowanych - jak i w administracyjnej pułapce nakazów i zakazów (Domosławski 2016, 138).

Na przykładzie opisanej przez Domosławskiego historii Beduinów z obozowiska Chan el-Ahmar widać teraźniejsze, ale i z pewnością przyszłe problemy z woda, wykorzystywana podczas permanentnej wojny o ziemie równie skutecznie jak broń. Władze okupacyjne przymusowo wysiedlają koczowni-

14 Tytuł podrozdziału jest metaforą pochodząca z tekstu P. Drembkowskiego $(2011,204)$. 
ków z rzekomo ich terenów ${ }^{15}$ pod budowę żydowskich osiedli, odcinając im stały dostęp do wody. Beduini, chcąc przeżyć, zmuszeni są do kradzieży wody przez dziurawienie rur. Wobec powtarzających się sytuacji tego typu władze izraelskie, kalkując poniesione straty, założyły kran z woda, jednak dawni koczownicy płacą za nią trzy razy więcej niż nowo przybyli mieszkańcy:

Izraelski sąd wykalkulował, że Beduini kradną i tak kilka razy mniej wody niż wycieka z dziurawej rury w ziemię. Nakazał więc władzom okupacyjnym założenie kranu dostępnego dla Beduinów. Ale ten kran ma licznik. Beduini płacą za metr sześcienny wody trzy razy więcej niż żydowscy osadnicy. Ci ostatni dostali od władz okupacyjnych cenę subsydiowaną w osadzie są eleganckie tereny zielone, a do ich utrzymania potrzeba dużo wody (Domosławski 2016, 139).

$\mathrm{Na}$ tym obszarze geograficznym woda stanowi jeden z największych problemów. Jego wagę akcentuje dramatyczna wypowiedź jednego z bohaterów, który złapany na kradzieży, pyta sędziego w trakcie rozprawy: „Nie mam wody dla siebie i swoich dzieci. Niech sąd powie: co mam zrobić?" (Domosławski 2016, 139). Życie na tych terenach staje się coraz trudniejsze dla ludzi pustyni, a globalne ocieplenie pogłębia dodatkowo nierówności bytowe i warunki przetrwania.

Niektóre scenariusze dotyczące przyszłości są już możliwe do przewidzenia $z$ powodu reglamentowania i niesprawiedliwego dystrybuowania wody pitnej. Nie potrzeba nawet wybiegać myślami w przód, by sobie to wszystko wyobrazić. Wystarczająco już trudna sytuacja między Palestyną i Izraelem może ulec zaostrzeniu, może również wzrosnąć liczba konfliktów lokalnych o ziemię i wodę, a także liczba uchodźców wewnętrznych i zewnętrznych, ludzie „niechciani” na tej ziemi zostaną odesłani na pustynię lub zostaną zabici. Walka o normalne życie uczyni z Palestyńczyków nowych wojowników, a nienawiść do ich wrogów spadnie na kolejne pokolenia, wówczas w tej części świata nigdy nie zapanuje już pokój. Na tym przykładzie widać również, że w przyszłości trudno będzie odróżnić uchodźców wojennych od środowiskowych, o czym pisał Harald Welzer. Konflikt ten ma również swoje uwarunkowania związane z zasobami naturalnymi i klimatem. Jakkolwiek

15 Więcej o tym problemie pisze P. Smoleński (2016, 36): „, pojawia się problem ziemi. Gdzie mają mieszkać Beduini (...), skoro Negew niemal w całości należy teraz do państwa żydowskiego? Mimo iż nomadzi mają poczucie - a niektórzy nawet dokumenty wydane jeszcze przez Turków i Brytyjczyków - że pustynia od wieków należała do nich”. 
związek między klimatem a wojną nie jest bezpośredni, to jednak pośrednio zapewne ma na nią wpływ.

Inną ilustracją walki o wodę jest przywołana przez Domosławskiego historia Aty. Autor relacjonuje jego kłopoty związane ze zbieraniem deszczówki:

Największy kłopot ma z wodą. Musi za nią płacić - więcej niż osadnicy. W porze deszczowej nie wolno mu zbierać deszczówki. Zgodnie z arbitralnym postanowieniem władz okupacyjnych woda na terytoriach okupowanych należy do Izraela, zbieranie deszczówki to zatem kradzież. Od czasu do czasu wojska robią najazdy i niszczą zbiorniki. Albo przyjeżdżają i wyrywają rurki nawadniające poletka deszczówką $(2016,173)$.

Przez rozmaite formy ograniczania wolności, jak zakaz zbierania deszczówki, władze Izraela chcą wypędzić Palestyńczyków. Wojsko na terenach okupowanych niszczy cysterny, zbiorniki i w sposób arbitralny narzuca nierówne zasady dla mieszkańców tego terenu - inne dla nowych osadników, inne dla mieszkających tam od lat Beduinów czy Palestyńczyków. Dzisiaj, kiedy rzadko dochodzi do zamachów i poważniejszych starć, Izraelczycy toczą, zupełnie inną niż klasyczna, wojnę. Zmiany klimatu stwarzają nie tylko nowe źródła konfliktów, ale i nowe formy interwencji zbrojnych (Welzer 2010, 113). Ponadto kreuja nowe zjawisko historycznej, globalnej niesprawiedliwości - istniejąca już asymetria szans życiowych zostaje pogłębiona przez zmiany klimatu i niesprawiedliwą dystrybucję surowców naturalnych (Welzer 2010, 55).

Walka o życiodajny surowiec wpisuje się w szerszy problemem geopolityczny. Wiedza z tego obszaru staje się punktem wyjścia do „trenowania” scenariuszy przyszłości. Snucie z młodzieżą potencjalnych przyszłych historii, które mogą wydarzyć się w tym regionie świata, warto rozpocząć od refleksji o tym, czy jest możliwe życie bez wody i do jakich czynów może popchnać człowieka jej brak. Tak rozpoczęta rozmowa pozwoli uzmysłowić młodzieży, do czego prowadzi zanikanie zasobów tak ważnych, jak ziemia czy woda. Prezentowane obrazy z teraźniejszości można zestawić również z przeszłościa - po to, by pokazać, że historia lubi się powtarzać i że „nie odrobiliśmy" zadanych dawniej lekcji. Ten kierunek można nakreślić przez przypomnienie systemów zniewolenia jednostki, takich jak apartheid. Warto pytać o to, czy mogą się one powtórzyć i stać się „przeszłą przyszłością” (termin za: Welzer 2010, 212). Jednocześnie, tworząc próbkę przyszłości, należy również przenieść punkt ciężkości ze snucia refleksji, wyobrażeń, wizji 
o dalszych formach konfliktów Palestyńczyków z Izraelczykami na myślenie o współpracy, koegzystencji, dobrym sąsiedztwie i przyjaźni, jak zaleca Domańska w koncepcji „historii ratowniczej”. W tym sensie trzeba zastanawiać się nad tym, co można zrobić, by skomplikowane relacje tych dwóch narodów mogły być w przyszłości lepsze (Domańska 2014, 17) ${ }^{16}$. Dlatego warto podjąć trud namysłu i wyobrażenia sobie innych pozytywnych form koegzystencji tych dwóch narodów w przyszłości. Jako przykład takiej perspektywy Domańska podaje projekt izraelskiej badaczki Arielli Azoulay, która zaproponowała stworzenie fotograficznego archiwum obywatelskiego. Ma ono na celu wydobycie kadrów, które wskazują na pokojowe możliwości współbycia Arabów i Żydów. Należy więc ożywić początkowo dobre relacje między tymi narodami, które akcentuja i Azoulay, i Domosławski. Myślenie nad tymi zagadnieniami pozwoli młodzieży odbyć mentalną podróż pomiędzy przeszłością i teraźniejszością a przyszłością, pozwoli tym samym zorientować się im na lepszą przyszłość.

\section{Susza}

Ben Rawlence, brytyjski afrykanista, w reportażu pt. Miasto Cierni. Najwiekeszy obóz dla uchodźcón podejmuje próbę pokazania przyczyn uchodzenia z m.in. takich państw jak Somalia, której środowisko naturalne uległo całkowitemu zniszczeniu. Autor omawianej publikacji odtworzył w kilku historiach powód migracji do Europy. Niewatpliwie głównym motywem jest zmiana klimatu: susze, brak dostępu do wody, gwałtowne równikowe nawałnice, prowadzące w konsekwencji do śmiercionośnych powodzi. Nawet jeśli życiu Somalijczyków bezpośrednio zagrażały islamskie bojówki z Asz-Szabab, to jednak w wielu przypadkach dopiero bezprecedensowy upał zmusił ich do przesiedlenia.

Informacje o tym regionie Afryki rozpoczyna rozdział ukazujący różnorodność trzech pór roku (hagar - pora wietrzna, dìiilaal - pora sucha i gu pora deszczowa), kiedy klimat był bardziej przewidywalny. Pory gu nie było jednak przez dwa lata z rzędu, a stan przedłużającej się suszy zniszczył

${ }^{16}$ „W tym sensie historia ratownicza jako historia potencjalna wpisuje się w zauważalny w dzisiejszej humanistyce i naukach społecznych proces przenoszenia punktu ciężkości z badań konfliktów na badania współpracy, koegzystencji, dobrego sąsiedztwa i przyjaźni” (Domańska 2014, 17). 
w Somalii plony i unicestwił źródła. Rolnicy oraz koczownicy musieli wyprzedawać swoje stada, nie było gdzie ich napoić, kobiety nie miały czym wykarmić rodzin, a dzieci umierały z głodu i pragnienia.

Somalijska ziemia nie zaznała deszczu od ponad dwóch lat. W roku 2010 nie padało od wierzchołka Rogu Afryki (...) Koczownicy i rolnicy widzieli chmury nadciagające ze wschodu, znad Oceanu Indyjskiego, nad czerwone równiny i płowe wzgórza, ale deszcz nie spadł. Widzieli, jak słabną zwierzęta, jak zboża uginają się pod ciężarem kurzu, i ogarniał ich smutek (Rawlence 2017, 23).

Narracja Bena Rawlence'a operuje kolorami, nadchodząca tragedia przybiera barwy sepii. Charakterystyczne brązowe odcienie przypominają wysuszona ziemię, pył wypalonych równin, ale także przemijające pokolenia ludzi.

Drugim, oprócz suszy i wynikającego z niej głodu, bohaterem książki jest wojna. „Głód i wojna szły zawsze w parze” (Rawlence 2017, 24) - czytamy w reportażu. Islamscy ekstremiści z Asz-Szabab pobierają podatki i zabierają coraz więcej i tak już ubogim ludziom, również wodę. Przez miejscowych nazywani są „,baronami rzecznymi”, kontrolują bowiem śluzy wodne. Kontrola ta była zresztą od początku zarzewiem wojny domowej w tej części świata. Nie dziwi więc, że większość Somalijczyków próbuje uciec z kraju. Część mieszkańców udała się za granicę, większość zaś do tymczasowego, dramatycznie przeludnionego obozu dla uchodźców w Dadaab, w północnej Kenii, położonego na blisko $80 \mathrm{~km}^{2}$ powierzchni ${ }^{17}$.

Wśród bohaterów, którym autor oddał głos w reportażu, jest Isza. Kobieta wraz z pięciorgiem dzieci wędrowała pieszo z Somalii do obozu dla uchodźców w Kenii, choć bardzo długo walczyła z suszą i głodem, próbując normalnie żyć w swojej wiosce o symbolicznej nazwie Rebay (w tłumaczeniu z somalijskiego „miejsce pobytu”). Wiedziała bowiem, iż opuszczenie domu oznaczało utratę wszystkiego.

Przez ostatnie trzy lata głód spowszedniał. Isza przywykła do krwawiących dziąseł, stanu zapalnego kończyn, skurczów przy przełykaniu płynów i cierpienia, jakie sprawia pusty żołądek, kiedy trawi sam siebie (...). Mężczyzna mówi: „To są twoje dzieci”, i znika, ale kobieta nie może porzucić potomstwa. Mieszkańcy Rebay spoglądali zatroskani w niebo, patrzyli po sobie i nie mieli nic do powiedzenia (Rawlence 2017, 73-74).

17 Informacje na podstawie rozdziałów: Róg Afryki (Rawlence 2017, 23-25) oraz Isqua (Rawlence $2017,70-74)$. 
Jej życie w prowizorycznym mieście namiotów również nie było łatwe, podobnie jak życie innych przebywających z nią uchodźców. Największym marzeniem mieszkańców tego ,gigantycznego, wielonarodowościowego miasta błota, namiotów i cierni”, jak je określił Rawlence (2017, 45), jest ucieczka do Ameryki, Kanady czy Europy. Za nią bez wahania większość z nich gotowa jest oddać życie. Formuła-okrzyk $W$ tocby albo śmieŕ́, tytuł jednego z rozdziałów reportażu, pokazuje, że perspektywa utonięcia czy skonania $z$ pragnienia na pustyni nie jest tym ludziom tak straszna, jak pozostanie na miejscu. Ten niemal okrzyk bojowy jest jak rękawica rzucona Włochom i Staremu Kontynentowi, mimo że w tym obszarze wzmocniono kontrole wybrzeża od strony Morza Śródziemnego. Wyjazd z obozu staje się właściwie jedyną drogą do normalności, a życie poza Dadaab w tej części Afryki nie daje wiele więcej. Wyprawa do Europy ma również charakter podróży inicjacyjnej, czyni z chłopca mężczyznę, pozwala cieszyć się w klanie estymą i dowodzi, że podoła on wypełnić obowiązki ojca:

„Gdybym miał pieniądze, podołałbym trudom podróży”, mówił sobie w duchu Guled. Czuł się bezsilny, nie był w stanie zadbać o własną rodzinę. Na to najczęściej skarżyli się mężczyźni w obozie. Mężczyzna, który nie umie zadbać o rodzinę, nie ma prawa głosu w radzie klanu, tak naprawdę w ogóle nie jest mężczyzną (Rawlence 2017, 289).

Somalia jest odzwierciedleniem czekających nas problemów z klimatem, wojnami, a w konsekwencji - z migracja. Zmiany klimatu moga powodować ogromne zagrożenia społeczne, np. wojny domowe, ludobójstwo, nowe formy przemocy i wykluczania ludzi ,niechcianych”. Form tych nie jesteśmy sobie jeszcze w stanie wyobrazić. Rację ma Welzer, pisząc, że kiedy żyje się w świecie, w którym nigdy nie było problemów z wodą czy suszą i wynikającymi z nich głodem czy chaosem, to można żywić przekonanie, że tego typu kwestie przewidziane są dla innych i nas nie dotycza. Taka zachodnia optyka spoglądania na Afrykę ulega dziś przekształceniu, a kryzys klimatyczny stał się faktem. Choć dotkną najpierw Południe, to jego skutki odczuwamy, obserwując losy tysięcy przybyszy szukających dla siebie odpowiednich warunków do życia.

Lekcja przyszłości na podstawie tego reportażu miałaby za zadanie uzmysłowić uczniom, że stabilność środowiska nie jest czymś danym raz na zawsze. Konsekwencje zmian klimatu pogłębiają i tak już trudną sytuację niektórych państw, do tego rośnie asymetria pomiędzy krajami najbiedniejszymi i najbogatszymi. Regiony, które najsłabiej przyczyniły się do emisji gazów 
cieplarnianych, są najsilniej dotknięte ich skutkami. Jak rozłożą się więc w przyszłości „obciążenia” powodujące katastrofy klimatyczne w wymiarze planetarnym, narodowym i pokoleniowym? Trzeba cały czas rozmawiać o zwiększającej się liczbie uchodźców klimatycznych i o tym, jak ich sytuacja wpłynie na zaostrzenie konfliktów wewnątrz państw i między państwami, a także o wykorzystaniu nowych form przemocy względem nich. Rozmawiajmy jednak przede wszystkim o życiu - o formach działań, które już teraz powinniśmy zainicjować, aby na ciasnym kawałku Ziemi przetrwała wspólnota ludzka.

\section{Przełowienia}

Innym przykładem ukazującym przyczynę wzmożonych migracji środowiskowych są kończące się zasoby morskie, a szczegółowo rzecz ujmując grabieżcze przełowienia ${ }^{18}$. Opis największych chyba zagrożeń dla morskich ekosystemów odnajdujemy w książce reportażowej Stefana Libertiego pt. Na południe od Lampedusy. Podróże rozpaczy. Mimo iż procesy te nazywa się katastrofami naturalnymi, to niewatpliwie ich źródła mają pochodzenie antropogeniczne, skutki z kolei odczujemy zwłaszcza na płaszczyźnie społecznej. Oznaczają one prawie zawsze eskalację konfliktów dotyczących dalszego sposobu eksploatacji, a finalnie opuszczenie nienadających się już do zamieszkania i zdobywania pożywienia obszarów (Welzer 2010, 46). Nadmierne wykorzystanie i złe zarządzanie rybołówstwem prowadzi więc lokalnych rybaków do utraty przestrzeni życiowej, a w konsekwencji do szukania jej gdzie indziej.

W pierwszym rozdziale Mbour, Sengal. Plaża ustana pirogami jeden z bohaterów, szef związków zawodowych rybaków, stwierdza, że odpowiedzialność za kryzys przełowienia ryb ponoszą Europa i zachodni morscy kłusownicy. Mówi on tak:

niegdyś najbardziej zarybione morze na świecie stało się wyschniętą studnią w wyniku nielegalnych połowów prowadzonych przez wielkie kutry europejskie, bezkarnie ograbiające lokalne wody. Statki pływające pod różnym ban-

18 Więcej na ten temat w raporcie pt. Statki molochy: plaga oceanów. Szkodliwy wplyw wielkich koncernów połowowych na rybołówstwo Unii Europejskiej oraz zasoby naturalne swiatowych mórz $i$ oceanów. Zob. http://www.greenpeace.org/poland/pl/press-centre/dokumenty-i-raporty/Raport -Statki-molochy-plaga-oceanow/ [dostęp: 29.03.2019]. 
derami, szczególnie hiszpańskie i francuskie, wypływały na szerokie morze Senegalu i plądrowały je do woli. (...) Europa nie może pozostać obojętna wobec tej tragedii. Przede wszystkim nie może zamykać oczu, gdy europejskie łodzie kradną nam ryby, a potem narzekać, że nasi chłopcy płyną szukać szczęścia na Wyspach Kanaryjskich (Liberti 2013, 20; 22).

Przekraczanie miary w eksploatowaniu przyrody należy rozpatrywać na płaszczyźnie etycznej. Zakłada ona, że stosunek do przyrody oparty jest na wartościach. Przedmiotem wykroczenia sa w tym przypadku ryby, zaś podmiotem dokonującym aktu przełowienia stają się nie tylko kutry pod różnymi banderami, ale i opinia społeczna oraz konkretny zleceniodawca - Unia Europejska, które ignoruja problem. W tekście uwidacznia się charakterystyczne z perspektywy postkolonialnej (Domańska 2008, 158) ${ }^{19}$ poczucie nadrzędności, ale i bezkarności Europy wobec Afryki. Trwająca eksploatacja wód i neokolonializm wywołany ekspansją kapitalizmu i procesami globalizacji jeszcze bardziej zwiększyły przepaść między bogatymi a biednymi. Wobec tego Senegalczycy obarczaja władze Starego Kontynentu winą za „kradzież ryb”, która zmusza ich do migracji (Liberti 2013, 25) ${ }^{20}$. Dzieje się tak, ponieważ europejskie statki-molochy łowią tak duże ilości ryb, że przekraczają one naturalne możliwości odradzania się ławic. Migracja lokalnych rybaków nie jest powodowana chęcią doraźnego wzbogacenia się, lecz przede wszystkim wolą przeżycia. Istnieje więc ścisły związek między migracja a kryzysem rybołówstwa, choć oczywiście nie jest to jedyny czynnik, który skłania Senegalczyków do wyjazdu.

Reportaż dobrze egzemplifikuje jeszcze jedno zagadnienie. Przeprawa do Europy to również rodzaj rewanżu, poszukiwanie zadośćuczynienia za poniesione przez Afrykę krzywdy. W wypowiedziach bohaterów da się wyczuć piętno kolonialnej przeszłości:

przeprawy na Wyspy Kanaryjskie były odwetem, zemstą ograbionej Afryki, której synowie osiedlili się teraz tłumnie na ziemiach swoich grabieżców, jakby chcieli wymusić w ten sposób rekompensatę za doznane krzywdy (Liberti 2013, 22).

19 Podobnie jak Ewa Domańska uważam, że bezpieczniej jest mówić o perspektywie postkolonialnej wobec tak szerokiej i różnorodnej problematyki definiowania studiów postkolonialnych i teorii postkolonialnej.

20 Prawda jest bardziej złożona. Wina za ten stan rzeczy leży również częściowo po stronie Senegalczyków, którzy, by zwiększyć wydajność połowów, posługują się dynamitem. 
Europa w narracjach bohaterów istnieje prawie zawsze na dwa sposoby: jako przyszła, nowa i szczęśliwsza ojczyzna oraz jako grabieżca, ciemiężyciel starej ojczyzny. Jednocześnie państwa europejskie uprawiaja podobną antynomiczną narrację - skarżą się, że nie ma kto u nich pracować, budując równocześnie mury i deportując imigrantów. Reporter wprost nazywa to zjawisko „schizofrenią Europy” (Liberti 2013, 119), która z jednej strony potrzebuje imigrantów, a z drugiej - wydaje fortunę na obronę przed ich napływem.

Spadek bioróżnorodności nie odgrywa dziś dużej roli w debacie publicznej, a nieodwracalne wyczerpywanie zasobów jest rozważane niemal wyłącznie przez przyrodników. I nie byłoby w tym niczego złego, gdyby nie fakt, że w dyskusjach na ten temat nie słychać głośnego krzyku humanistów. Nikt nie oczekuje od nich wiedzy eksperckiej - przyrodniczej - czy tworzenia katalogu zagrożeń środowiskowych, który już zresztą powstał. Mogliby oni raczej wypełnić niszę dotyczącą społecznych scenariuszy przyszłości, ich projekcji dobrych rozwiązań problemów klimatycznych, migracyjnych, antycypowania niebezpieczeństw i potencjalność historii. Chodzi mi o zauważalny i wyrazisty głos humanistyczny pośród wypowiedzi performatywnych, które ustanawiają nowy stan rzeczy, które tłumaczą i negocjują znaczenia, które wreszcie podnoszą alarm - o takich głosach literaturoznawczych pisał niedawno Ryszard Koziołek (2017, 60-69). Dysponują oni wszak wglądem do największego repozytorium ludzkich działań - literatury. Taka perspektywa pozwoliłaby na namysł nad pozytywną zmiana, nad „humanistyczną odbudową" nie tylko Europy czy świata, ale i naszej planety. Zmiana przecież wciąż jeszcze jest możliwa. Dlatego warto stawiać następujące pytania: jakie społeczne, ekonomiczne i kulturowe skutki będą miały w przyszłości kończące się zasoby morskie, także w kontekście rozwoju społeczności nadbrzeżnych?, co Europa i świat mogą zrobić w takiej sytuacjị, jak odnawiać zasoby rybne i poprawiać stan wód?

Należałoby również zwrócić uwagę na współzależne kategorie użyte w wypowiedziach bohaterów reportażu. Są nimi: zemsta, odwet, sprawiedliwość. Pojawiają się one w niniejszych rozważaniach nieprzypadkowo, albowiem w wyniku antropogenicznych zmian klimatycznych poszerzą swój zakres. Dotyczyć będa już nie tylko relacji mieszkańców peryferii i centrum świata, ale również nas i kolejnych pokoleń (perspektywa naszych dzieci, wnuków). Nie bez powodu mówi się bowiem, iż Ziemi nie otrzymaliśmy od naszych ojców, tylko pożyczyliśmy ją od naszych wnuków.

Powinno się cały czas tworzyć także pozytywne scenariusze dotyczące wspólnej przyszłej egzystencji, zastanawiając się z jednej strony nad tym, jak 
wykorzystać potencjał doświadczeń migrantów środowiskowych, ale też, z drugiej strony, jakie stwarzać warunki, by go najpełniej wykorzystać. Należy pytać o wagę prowadzonej polityki międzynarodowej, co musi w niej zostać zmienione, a także zarysowywać wizję instytucji ponad- i transnarodowych (np.: ministerstwa środowiska, żywienia, rozbrojenia i pokoju, polityki migracji, związków zawodowych rybaków, wspólnych polityk i praw dotyczących ochrony środowiska), które mogłyby rozwiązywać globalne problemy, albo wymyślić taki styl życia, którego celem byłoby utrzymanie przyzwoitego standardu egzystencji wszystkich mieszkańców Ziemi, a nie tylko mieszkańców najbogatszych krajów.

W tym miejscu pożądane byłoby zdemaskowanie prezentowanych w pseudodialogach o uchodźstwie i ochronie klimatu mechanizmów fałszywych alternatyw. Jedną z takich alternatyw sygnalizuje pytanie: czy coraz liczniejszych eko-uchodźców będzie trzeba przetrzymywać w obozach, czy raczej pozwoli się im umrzeć we własnej ojczyźnie lub utonąć w morzu? Debata o uchodźcach i klimacie pełna jest takich pozornych dylematów, które tworzą „humanitarnie wyglądające strategie wykluczania” (Welzer 2010, 215). Warto poszukiwać wraz z uczniami dróg wyjścia z tych pułapek myślenia.

\section{Postscriptum}

Jako dydaktyk literatury zastanawiam się, dlaczego tak rzadko w szkołach i na uniwersytetach stosuje się metodę antycypowania i projekcji przyszłości. Ta spekulatywna metoda kształci myślenie sytuacyjne, postawy aktywnego uczestnictwa (partycypacji) w świecie i rozwija tak bardzo potrzebną nam w dzisiejszych czasach wyobraźnię. Akty wyobrażeniowe dają możliwość nieograniczonego kształtowania świata i wirtualnego rozgrywania kluczowych sytuacji społecznych, kulturowych i politycznych. Jedną z takich sytuacji jest z pewnością kryzys migracyjny wywołany działalnością człowieka w przyrodzie. Trenowanie się w tworzeniu ,scenariuszy przyszłości” pozwoli uczniom i studentom stać się, choć to może wielkie słowa, pionierami transformacji czy agentami zmian społecznych ${ }^{21}$. Dzięki tym działaniom z pewnością staną się także krytycznymi, kreatywnymi i aktywnymi obywatelami świata, którzy nie pozostaną obojętni na nadchodzącą rzeczywistość.

21 Określenia: „pionierzy Wielkiej Transformacji” i ,,agenci zmian” zaczerpnęłam z: Leggewie, Welzer, 2012, 7. 
Wyżej wspomniane lektury - choć są w istocie wołaniem o szacunek i godność każdego człowieka - stanowią równocześnie świadectwo skutków zmian klimatycznych i nadmiernej ingerencji człowieka w ekosystem. Wybrane fragmenty ukazują trzy realne sytuacje, które maja już miejsce na świecie, aczkolwiek w Europie nie odczuwamy ich jeszcze tak bardzo: prowadzenia wojen o wodę, występowania suszy oraz zanikania zasobów morskich. Literatura faktu ilustruje o wiele więcej przyczyn migracji środowiskowych np. z powodu awarii elektrowni atomowych (Boni 2016; Aleksijewicz 2012; Brown 2016), szkoda jednak, że ich lektura nie jest traktowana obligatoryjnie, bo przecież „literaturą myśli się i mówi lepiej niż innymi dyskursami” (Koziołek 2016, 20). To ona daje język mówienia o ważnych problemach społecznych, podpowiada przykłady, używa argumentów, dzięki którym znakomicie można kształtować obrazy przyszłości. Szkoła i uniwersytet nie mogą być dłużej obojętne na zmiany klimatyczne, których konsekwencją są migracje środowiskowe, a „polonistyka powinna odnaleźć się w szerokim kręgu nauk społecznych. Szkoła nie działa przecież w próżni”22 - wielokrotnie podkreślał Tadeusz Sławek. Jeśli wystarczająco ukierunkujemy wyobraźnię na zmiany klimatyczne, to lektura literatury pięknej może stanowić przyczynek do zaradzenia politycznej i gospodarczej ignorancji.

W dobie śmierci uniwersytetów klasycznych i paradygmatu badań wdrożeniowych pojawia się pytanie: czy potrzebujemy dziś humanistów? Mam nadzieję, że ten tekst, choć wymagający jeszcze dalszych analiz i rozwinięć oraz wypracowania w rzeczywistości lekcyjnej gotowego scenariusza przyszłości dopisanego do jednej z historii reportażowych, oddaje wagę odpowiedzialności społecznej humanistyki w kształceniu kolejnych pokoleń. Stanowi on także zachętę do zabierania głosu o performatywnej mocy i już nie tylko podnoszenia alarmu, co do włączania syren w debatach publicznych na temat zmian klimatu oraz uchodźstwa środowiskowego.

Słowa te nie są nadmiernie przesadne, ich wydźwięk powinien być już dziś alarmujący, bo jak wykrzyczał Dauda, bohater pierwszego rozdziału książki Libertiego, Afrykańczyk odesłany z Hiszpanii, wielka fala migrantów jest nieunikniona: „Naprawdę myślicie, że jesteście w stanie powstrzymać tę wezbraną falę ludzi?! Doprawdy sądzicie, że uda wam się nas zatrzymać?!” (Liberti 2013, 11).

${ }^{22}$ Słowa te zostały wypowiedziane podczas III Kongresu Dydaktyki Polonistycznej. Polonistyka $i$ świat wartości. Edukacja polonistyczna jako wartość organizowanego przez Katolicki Uniwersytet Lubelski Jana Pawła II w Lublinie w dniach 22-25 listopada 2017 roku w ramach panelu pt. Wartości i wartościowanie w polonistycznej dydaktyce uniwersyteckiej (sesja plenarna). 


\section{Literatura}

Aleksijewicz S., 2012, Czarnobylska modlitwa. Kronika prayszłości, przeł. Czech J., Wołowiec.

Bates D.C., 2002, Environmental Refugees? Classifying Human Migrations Caused by Environmental Change, „Population and Environment”, vol. 23, no. 5.

Boni K., 2016, Ganbare! Warsætaty umierania, Warszawa.

Brown K., 2016, Plutopia. Atomowe miasta i nieznane katastrofy nuklearne, przeł. Bieroń T., Wołowiec.

Derra A., 2013, Kobiety (w) nauce. Problem ptci we wspótczesnej filozofii nauki $i$ w praktyce badawczej, Warszawa.

Domańska E., 2017, Sprawiedliwość epistemiczna w bumanistyce zaangażowanej, „Teksty Drugie. Teoria literatury, krytyka, interpretacja”, nr 1.

Domańska E., 2014, Historia ratownicza, „Teksty Drugie. Teoria literatury, krytyka, interpretacja", nr 5 .

Domańska E., 2013, Humanistyka ekologiczna, „Teksty Drugie. Teoria literatury, krytyka, interpretacja", nr. 1-2.

Domańska E., 2008, Badania postkolonialne, w: Gandhi L., Teoria postkolonialna: wprowadzenie krytyczne, przeł. Serwański J., Poznań.

Domosławski A., 2016, Wykluczeni, Warszawa.

Drembkowski P., 2011, Wojna o niebieskie złoto, „Zeszyty Naukowe WSOWL”, nr 3 (161).

El-Hinnawi E., 1985, Environmental Refugees, Nairobi.

Fiedorczuk J., 2015, Cyborg w ogrodzie. Wprowadzenie do ekokrytyki, Gdańsk.

Ghosh A., 2016, The Great Derangement: Climate Change and the Unthinkable, Londyn.

Koc K., 2018, Lekecje myślenia (obywatelskiego). Edukacja polonistycżna wobec wspótcz̨esnego świata, Poznań.

Kościerzyńska J., Chmiel M., Szulc M., Gorzałczyńska-Mróz A., 2017, Nowe stowa na start!. Podrecznik do jezykea polskiego dla klasy siódmej szkeoly podstawowej, Warszawa.

Koziołek R., 2017, Humanistyka literaturoznawcza w dobie nowych konfliktów plemiennych. Próba wykonania ruchu, ,'Teksty Drugie. Teoria literatury, krytyka, interpretacja”, nr 1.

Koziołek R., 2016, Dobrže się myśli literatura, Katowice.

Leggewie C., Welzer H., 2012, Koniec świata, jaki znalismy. Klimat, przyszłłośc i szanse demokracji, przeł. Buras P., Warszawa.

Liberti S., 2013, Na południe od Lampedusy. Podróże rozpaczy, przeł. Wyrembelski M., Wołowiec.

Massumi B., 2015, Ontopower. War, Powers, and the State of Perception, Durham-London.

Ojciec Święty Franciszek, 2015, Encyklika Laudatio si. W trosce o wspólnym dom, Kraków.

Nycz R., 2017, Kultura jako czasownik. Sondowanie nowej bumanistyki, Warszawa.

Rawlence B., 2017, Miasto cierni. Największy obóz dla uchodźców, przeł. Kowalski S., Wołowiec.

Smoleński P., 2016, Wieje szarkijja. Beduini zpustyni Negew, Wołowiec.

Tabaszewska J., 2017, Przeszłe przysz̨łości. Afektywne fakty i bistorie alternatywne, „Teksty Drugie. Teoria literatury, krytyka, interpretacja", nr 5.

Welzer H., 2010, Wojny klimatyczne: za co będriemy zabijać w XXI wieku?, przeł. Sutowski M., Warszawa.

Ząbek M., 2018, Uchodźcy w Afryce. Etnografia przemocy i cierpienia, Warszawa. 


\section{Netografia}

Adhortacja apostolska Evangelii Gaudium Ojca Świetego Francisqka do biskupów, prezbiterów i diakonów do osób konsekrowanych do wiernych świeckich o głoszeniu Ewangelii we współczesnym świecie, https:/ / w2.vatican.va/content/dam/francesco/pdf/apost_exhortations/documents/papa-frances co_esortazione-ap_20131124_evangelii-gaudium_pl.pdf [dostęp: 23.02.2019].

Ficek E., Ochwat M., Sujkowska-Sobisz K., Wójcik-Dudek M., red., 2018, Społeczeństwo obywatelskie: edukacja, wartości, style komunikacyjne, Katowice, http://www.spoleczenstwoobywatels kie.edu.pl/\#p=13[dostęp: 23.02.2019].

Ghosh A., 2016, Where is the fiction about climate change?, „The Guardian”, 28.10.2016 r., https://www.theguardian.com/books/2016/oct/28/amitav-ghosh-where-is-the-fiction-ab out-climate-change- [dostęp: 31.03.2019].

http://www.greenpeace.org/poland/pl/press-centre/dokumenty-i-raporty/Raport-Statki-mo lochy-plaga-oceanow/ [dostęp: 29.03.2019].

http://www.interakcja-integracja-2018.us.edu.pl/humanista-sygnalista/ [dostęp: 23.02.2019]. 